\title{
Identification of Factors Influencing Sustainability of Buried Continuous Pipelines
}

\author{
Muhammad Rizwan Akram *(1) and Abdullah Can ZÜLFIKAR \\ Department of Civil Engineering, Gebze Technical University, Cumhuriyet, 2254. Sk. No:2, \\ 41400 Gebze/Kocaeli, Turkey; aczulfikar@gtu.edu.tr \\ * Correspondence: mrakram@gtu.edu.tr; Tel.: +90-555-0993066
}

Received: 4 January 2020; Accepted: 24 January 2020; Published: 28 January 2020

check for updates

\begin{abstract}
Threat to the sustainability of buried continuous pipelines (BCPs) can be associated with different factors such as corrosion, natural hazards, and third-party influences. In the past, these factors have been discussed independently by various researchers. Despite these studies, there is still space for a comprehensive review report to be performed in this domain. The purpose of this article is to manage, classify, and describe the literature work done in this sphere. Firstly, the screening of various factors based on their damage criteria has been carried out. An environmental analysis is performed to review the impact of different parameters that can influence the sustainability of BCPs. Further, a technical review on primary factors has been done to examine and measure the causes, damages, mitigation, and inspection techniques. In the last stage, review based decision has been performed. Results of the current study shows that research contribution for corrosion and earthquake factors are in an advanced stage, followed by flood and external surface loads, that are still in progress. However, temperature variations and blast factors are in a premature phase and need broad inspection and research support.
\end{abstract}

Keywords: buried continuous pipelines; corrosion; earthquake; flood; temperature; blast

\section{Introduction}

Pipelines are important lifeline elements as they transport oil, gas, water, petrol, and other such fluids long distances. They are usually buried in soil because of safety, environmental, and economic reasons. Depending on their material compositions, buried pipelines are generally divided into two types; one is made of steel or its composite alloys and are known as buried continuous pipelines (BCPs). Others are commonly made of concrete and are classified as segmented pipelines [1]. BCPs are considered as the financial backbones of a nation, and any threat to their operation can trigger losses of billions of dollars [2]. In the past, various factors have been discussed independently that can influence the sustainability of BCPs.

Among those factors, corrosion decides the life cycle of BCPs [3-8] due to the degradation of steel material that ends up with failure [9-11]. This is an important parameter in terms of economical maintenance and necessitates the continuous inspection and replacement of BCPs. Another parameter that affects the structural stability of BCPs is temperature difference due to climate change [12-14]. The temperature variation between a pipe's internal and external surfaces has more impact on its sustainability than the external environmental changes [15]. Further, external surface load such as traffic, heavy equipment, and superstructure built on the BCPs also impact its integrity [16-25]. Likewise, flood [26-34], blasting [35-37] and earthquakes [38-44] also affect the safe operations of BCPs.

It has been noticed that many articles related to the discussed topic are available; however, the topic is still confused, unclear, and has conflicts. Despite these studies, there is still space for a comprehensive review report to be performed in this domain. The current research manages, classifies, 
and fills the gap in this sphere. Six primary factors (corrosion, earthquake, flood, external loads, temperature variation, and blasting) are identified and are discussed in detail.

The steps involved in the current study have been shown in the form of a flow chart in Figure 1. In the first stage, a problem statement has been identified. After that, the screening of various factors that can influence the problem statement has been carried out and the results are classified into three groups; primary, secondary, and tertiary factors. Primary factors are chosen for environmental analysis. Further, a comprehensive technical review on primary factors has been done to investigate and determine their aspects, impacts, mitigation, and inspection techniques. In the last stage, review based assessment has been presented and the scientific contributions of this study have been clarified. This review article not only presents a summary of relevant streams of thoughts but also includes new perceptions on advancements in this area. It is believed that the current review article is a good source for future research.

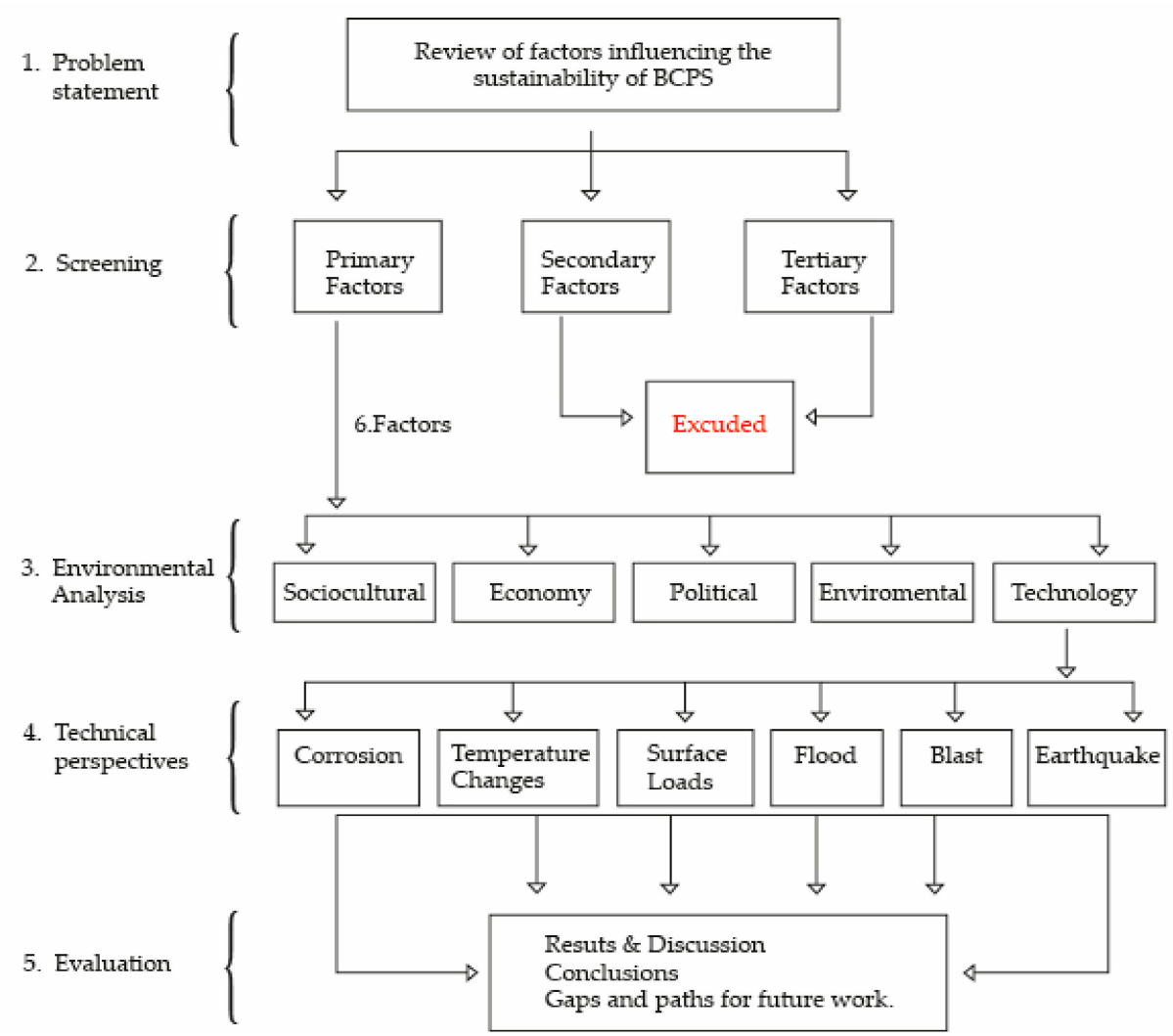

Figure 1. Flow diagram: review-based analysis of buried continuous pipelines (BCPs).

\section{Screening of Various Factors}

There are various factors that can affect the safe operation of BCPs. Many researchers have contributed in this realm and have explained the aspects and impacts of these factors. In the current study, five steps (selection, screening, eligibility, and included) have been made to decide and classify these factors. In the selection stage, several published articles based on specific keywords have been collected from diverse databases. Then, the screening of these factors has been made after abstract reading. An eligibility analysis is performed to check the aspects and impacts of the selected factors. Afterward, a decision (Included) is finalized to classify the factor as primary, secondary, or tertiary.

Factors based on high potential damage to BCPs are classified as primary factors. In the current study, six factors such as corrosion, temperature variations, external surface loads, flood, blasting, and earthquake have been considered in this category. Likewise, the factors that may influence the sustainability of $\mathrm{BCPs}$ are grouped as secondary factors. There can be excavation damage, incorrect installation, pipe manufacturing errors, high pressure, and exposure to direct sun rays. Further, factors 
that happen rarely and may have a minor influence on the sustainability of BCPs are termed as tertiary factors. These factors can be falling hail, acid rain, tree roots, or birds perching on pipes and scratching their coating of surface paint with their talons. The process of screening is shown in Figure 2.

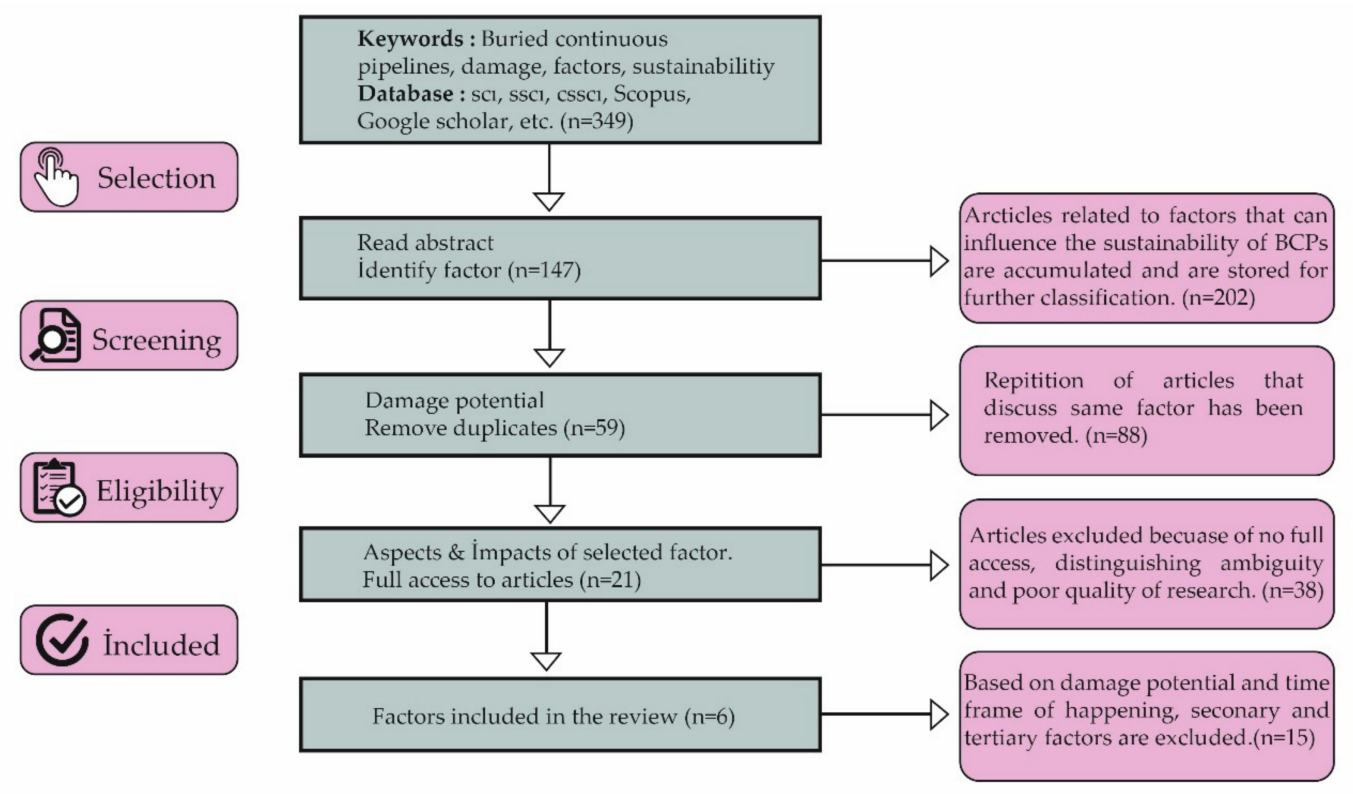

Figure 2. Screening process of primary, secondary, and tertiary factors.

\section{Environmental Analysis}

In the primary factors, corrosion determines the life cycle of BCPs due to the deterioration of steel material that ends up with collapse [3]. It is an essential factor in terms of cost-effective maintenance and needs constant examination. Likewise, temperature differences due to climate difference can also disturb the structural stability of BCPs [14]. The temperature variation between the interior and exterior surfaces of the pipe has more influence on its sustainability than the outside environmental changes [15]. Further, external surface loads such as traffic, heavy equipment, and superstructure constructed on the BCPs also impact its integrity. Similarly, human actions, i.e., blasting, and natural forces such as floods and earthquakes can also affect their safe operation.

In the current study, an environmental analysis is performed to analyze various parameters that can impact the sustainability of BCPs. Firstly, it can be noticed that socio-cultural aspects are one of the main parameters for environmental analysis. Pipelines are labeled as the lifelines of a society. Any interruption to their operation can affect the supply of potable water, cutoff natural gas, and liquefied petroleum gas (LPG), or could cause a petroleum crisis. Therefore, regular seminars and workshops should be arranged for the promotion of awareness in societies about the importance and safety of these pipelines.

Another important parameter for environmental analysis is economy. Any damage to BCPs can trigger a significant threat to the economy of a nation. Figure 3 shows the total cost spent on the stability of pipelines in the USA between 1999 and 2018, as reported by Pipeline and Hazardous Materials Safety Administration (PHMSA) [2]. Therefore, to support the safety of BCPs, there should be financial support for the rehabilitation and maintenance of these utilities.

Likewise, political influence is also an important parameter for the environmental analysis. There are several aspects, such as international sanctions, a country's poor design standards, election campaign manifestos, flexibility in bidding the project, and financial breakdown, that can influence the integrity of BCPs. There should be rigid amendments in the law to secure these pipelines carefully from political influences. 
A clean environment means safe health. However, it is observed that leakage of material from wastewater pipelines pollute the environment and spread diseases. There is also an increase in global warming due to intermittent leakage of gases from the buried pipes. Also, the leakage in offshore pipes can cause the death of sea animals. There should be proper risk assessments, inspections tools, emergency controls, institutional objectives, and warning policies.

Today, technology has contributed well to analyze the factors, their causes, and damages, and can provide innovative solutions for their mitigations and inspections. This issue is addressed in detail in the next section. Figure 4. presents the environmental analysis, its impacts and aspects on sustainability of buried pipelines.

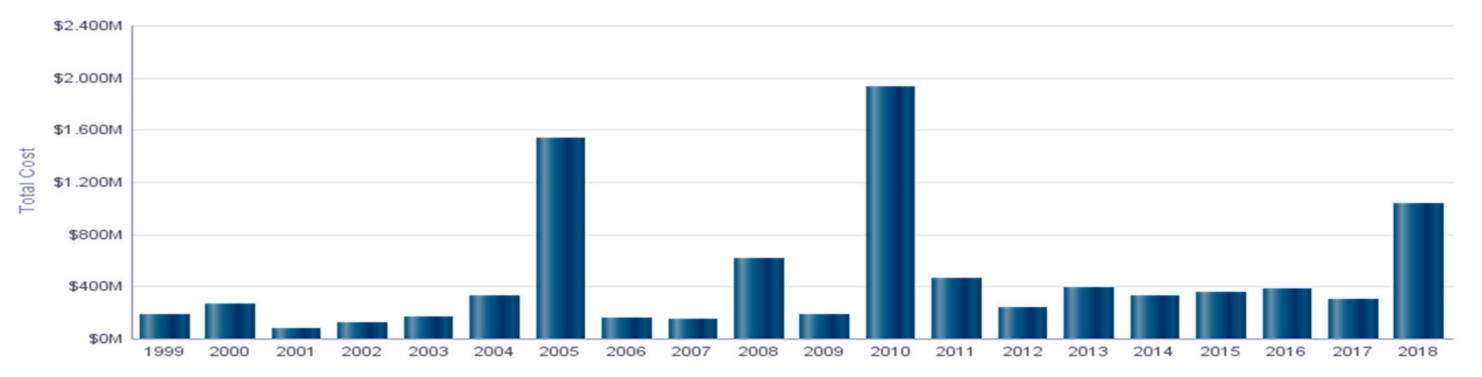

Figure 3. Total cost spent on the stability of BCPs between 1999 and 2018 [2].

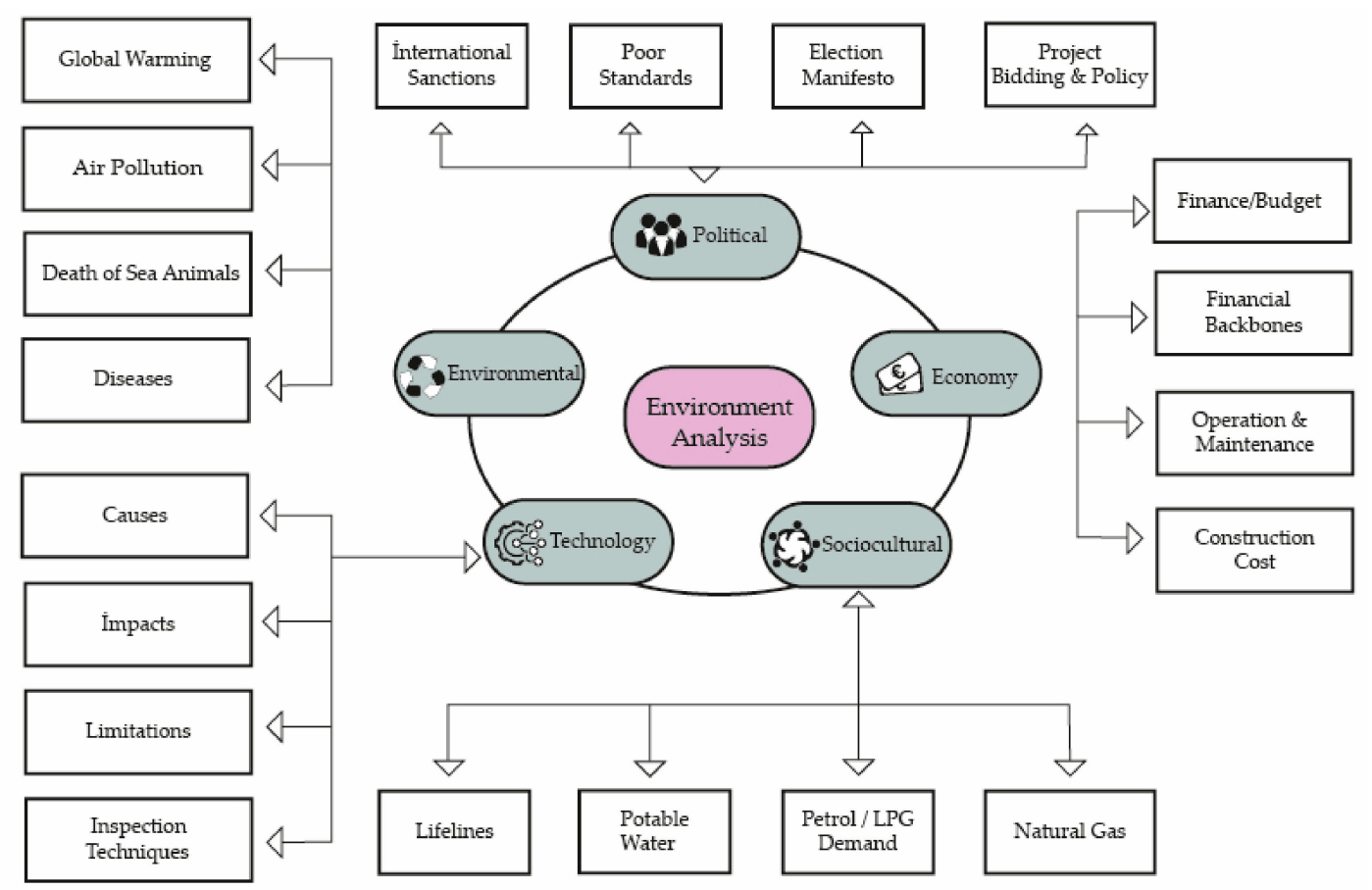

Figure 4. Environmental analysis, its aspects, and impacts on sustainability of BCPs.

\section{Analysis of Primary Factors in Technical Perspectives}

In this section, the technical perspectives of six primary factors have been discussed. Review based study has been performed to analyze the causes, damages, and mitigation techniques. Further, advancements in inspection techniques have also been observed.

\subsection{Corrosion}

$\mathrm{BCPs}$ are essential components of our infrastructure system, but these facilities are continuously facing threat due to electrochemical deterioration known as corrosion. In Table 1, six common types of 
corrosion, their causes, damages, and advances in mitigation techniques have been listed. Surface metal loss, pitting, cavitation, and stray current corrosions have been detected in all types of BCPs. However, cavitation, erosion, and microbiologically induced corrosions are observed only in iron made water pipes.

Table 1. Corrosion types, causes, damages, and mitigation techniques.

\begin{tabular}{|c|c|c|c|c|}
\hline Types & Causes & Damage & Mitigation Techniques & Ref \\
\hline Surface metal loss & $\begin{array}{l}\text { Damage to the external } \\
\text { surface/ surface paint }\end{array}$ & Leakage/rupture of BCPs & $\begin{array}{l}\text { Cathodic protection or } \\
\text { external pipe } \\
\text { surface coating }\end{array}$ & [3] \\
\hline Pitting & $\begin{array}{l}\text { Protective film exposition or } \\
\text { chlorides attack }\end{array}$ & $\begin{array}{l}\text { Deterioration of pipe } \\
\text { surface area }\end{array}$ & $\begin{array}{l}\text { Selection of right } \\
\text { material for pipes and } \\
\text { cathodic process }\end{array}$ & [4] \\
\hline Cavitation & $\begin{array}{l}\text { Sudden drop of fluid } \\
\text { pressure and then its } \\
\text { vapor pressure }\end{array}$ & $\begin{array}{l}\text { Collapse of internal } \\
\text { surface of pipe }\end{array}$ & $\begin{array}{l}\text { Minimizing fluid } \\
\text { pressure gradients and } \\
\text { right coatings }\end{array}$ & [5] \\
\hline Erosion & $\begin{array}{l}\text { Relevant fluid movement } \\
\text { against internal pipe surface }\end{array}$ & Turbulence in fluid flow & $\begin{array}{l}\text { Careful selection of wear } \\
\text { resistance material for } \\
\text { buried pipes }\end{array}$ & [6] \\
\hline Stray Current & $\begin{array}{l}\text { Stray currents due to electric } \\
\text { driven railways, welding } \\
\text { machines, DC sources, } \\
\text { and cathodic protections }\end{array}$ & Pit holes on the pipe & $\begin{array}{l}\text { Controlling electricity } \\
\text { leakage or protective } \\
\text { system from } \\
\text { stray currents }\end{array}$ & [7] \\
\hline $\begin{array}{l}\text { Microbiology } \\
\text { Influenced }\end{array}$ & $\begin{array}{l}\text { Metabolic activity of } \\
\text { microorganisms }\end{array}$ & $\begin{array}{l}\text { Deterioration of pipe } \\
\text { surface area }\end{array}$ & $\begin{array}{l}\text { Using sulphate } \\
\text { reducing bacteria }\end{array}$ & [8] \\
\hline
\end{tabular}

Corrosion is like a cancer for BCPs as it slowly deteriorates the internal and external surfaces. Once it happens, it causes flaws inside the pipe coating that result in the leakage of materials. In Figure 5, four types of corrosion have been displayed. Figure 5a shows the external surface corrosion that usually happens due to the damage of external surface and can be handled by using cathodic protection technique or by the application of new coatings/painting on the external surface. Figure $5 \mathrm{~b}$ presents the damage of pipes due to stray current. Direct stray currents from electric trains, electric towers, or electric motors accumulate on buried pipes and induce pit holes on their surface. Figure $5 \mathrm{c}$ shows the pitting corrosion that usually happens on passive metals or their composite alloys. This is usually caused by damage to the external thin layer, also known as the oxide film, and generates pits on the damaged surface. Erosion corrosion happens in buried water pipes and is shown in Figure 5d. Significant factors influencing erosion corrosion are chemical alignment of the pressure periphery, $\mathrm{pH}$ amount, heat and oxygen quantity, and instability in fluid flow.
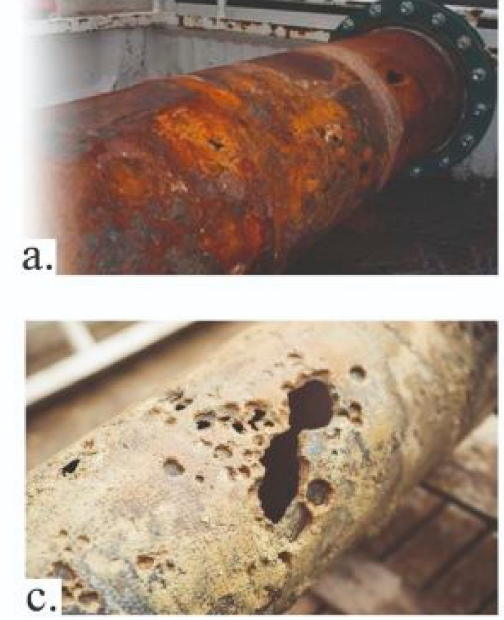
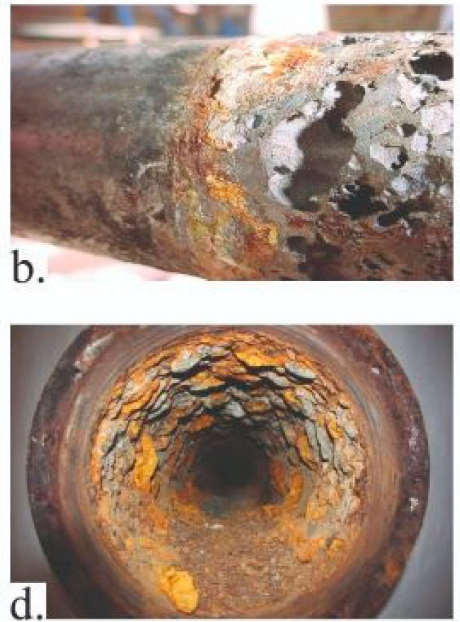

Figure 5. BCPs exposed to different corrosions; (a) Metal loss; (b) Stray current; (c) Pitting; (d) Erosion. 
In recent years, composite sectors have introduced innovative materials to protect the buried pipelines from corrosion. In the study carried out by Sahar and Mohammad [9], epoxy-based resin was found to be more resistant to corrosion-based damage for buried pipelines than unsaturated polyester resins. In the past research, various inspection techniques have been described to overcome this damaging factor. Table 2 summarizes the literature studies carried out on inspection methods and their advantages and limitations in corrosion assessment.

Table 2. Inspection methods, advantages and limitations.

\begin{tabular}{cccc}
\hline Inspection Method & Advantages & Limitations & Ref. \\
\hline Magnetic flux leakage (MFL) & $\begin{array}{c}\text { Identifies flux leakage over metal loss defects, } \\
\text { detects deformations in pipes, and is widely } \\
\text { used for pitting corrosions inspections }\end{array}$ & $\begin{array}{c}\text { Difficult to measure correct } \\
\text { readings when flaw is too small. }\end{array}$ & {$[10]$} \\
\hline Ultrasonic devices & $\begin{array}{c}\text { Good for measuring mid wall corrosion defects } \\
\text { and actual pipe wall width }\end{array}$ & $\begin{array}{c}\text { Weak at identifying and sizing } \\
\text { corrosion pits. } \\
\text { Echo-loss limitation. }\end{array}$ & [11] \\
\hline
\end{tabular}

In Table 2, it is noticed that both classical and advanced methods are available for corrosion inspection. However, the complication of corrosion procedure is arbitrary in nature and has made estimating corrosion complex. Due to the extensive length of buried pipeline systems, corrosion of BCPs cannot be avoided; however, it can be identified, evaluated, examined, and handled.

\subsection{Temperature Changes}

One of the physical factors that can influence the operation of BCPs is the temperature. Seasonal changes, generally in cold weathers, increase pipeline failures. In addition, temperature differences (TD) inside the BCP and its surrounding soil can cause contraction or expansion that leads to failure. There are novel methods available to detect changes of fluid rate in BCPs due to TD. In the literature studies, two types of failure due to temperature changes have been summarized in Table 3.

Table 3. Type of failure, its causes, and damages.

\begin{tabular}{cccc}
\hline Failure Type & Causes & Damages & Ref. \\
\hline Contraction/Expansion & Winter/Summer seasons & Axial and & circumferential strain \\
$\begin{array}{c}\text { External and Internal } \\
\text { temperature differences (TD) }\end{array}$ & $\begin{array}{c}\text { Surface and } \\
\text { underground TD }\end{array}$ & Damage to the pipe wall & [13] \\
\hline
\end{tabular}

The inspection techniques used for the measurement of TD in BCPs are somewhat like corrosion. It is observed that most of the devices used for corrosion measurement can also detect TD in BCPs. Some common techniques, with their advantages and limitations, are given in Table 4 .

Table 4. Inspection techniques, its advantages, and limitation.

\begin{tabular}{|c|c|c|c|}
\hline Inspection Technique & Advantages & Limitations & Ref \\
\hline $\begin{array}{l}\text { Pipeline inspection } \\
\text { gauges (PIGs) }\end{array}$ & $\begin{array}{l}\text { Uses few sensors, provides information } \\
\text { about the internal geometry of } \\
\text { the pipeline }\end{array}$ & Used at large scale level & [11] \\
\hline Infrared remote sensing & Rapidly detects leakage point & $\begin{array}{l}\text { Hurdles can cause trouble } \\
\text { in measurements }\end{array}$ & [14] \\
\hline $\begin{array}{c}\text { Distributed } \\
\text { temperature sensor }\end{array}$ & $\begin{array}{l}\text { Does not require a new installation of } \\
\text { equipment, provides high accuracy and } \\
\text { economical technique }\end{array}$ & $\begin{array}{l}\text { Still not used in real pipelines, } \\
\text { only available for } \\
\text { laboratory investigations }\end{array}$ & [15] \\
\hline
\end{tabular}

It is recognized that failures to buried pipes due to temperature variations has attracted less attention in past. Only a few studies related to water mains are available. So, there is still space for experimental and numerical studies to be carried out on BCPs in this realm. This factor is more critical 
for regions with extreme weather conditions. Frost load or swelling soil phenomena can cause circular or circumferential breaks in BCPs. Moreover, frozen water inside the buried pipes can cause hoop stress failure.

\subsection{External Surface Loads}

External surface loads such as dead and live loads are very important in the design procedure for buried pipelines. Dead load may be due to self-building weight, heavy machinery, or soil resting on buried pipes. Similarly, live load can be due to moving objects such as trucks, trains, buses, or landing airplanes. Table. 5 presents previous studies carried out on the truck load effects on buried pipes.

In Table 5, it is noticed that there have been advances in research related to live load (i.e. traffic load) effects on BCPs. However, minor attention has been paid on the failure of BCPs due to dead load. There are various advanced protection methods available to protect the buried pipes from external surface loads. Some of these practices are described in Table 6.

Table 5. Previous studies related to the effect of traffic loads on buried pipelines.

\begin{tabular}{|c|c|c|c|c|c|c|}
\hline $\begin{array}{c}\text { Analysis } \\
\text { Type }\end{array}$ & Pipe Material & $\begin{array}{l}\text { Diameter } \\
\text { (m) }\end{array}$ & $\begin{array}{c}\text { Back Fill } \\
\text { Height (m) }\end{array}$ & $\begin{array}{l}\text { Number } \\
\text { of Trucks }\end{array}$ & $\begin{array}{l}\text { Max. Axle } \\
\text { Load } \\
\text { (KN) }\end{array}$ & Ref. \\
\hline $\mathrm{FEA}^{1} / 3 \mathrm{D}$ & $\mathrm{HDPE}^{2}, \mathrm{PVC}^{3}, \mathrm{St}^{4}, \mathrm{AL}^{5}$ & 0.90 & $0.45-1.80$ & 2 & 181 & [16] \\
\hline FEA/2D & HDPE and PVC & $0.3-1.5$ & $0.1-2.8$ & 2 & 178 & [17] \\
\hline FEA & St & $0.9-1.2$ & $0.54-0.77$ & 1 & 133 & [18] \\
\hline FEA/3D & St & 0.9 & 0.5 & 1 & 588 & [19] \\
\hline FEA/3D & $\mathrm{RC}^{6}$ & 0.8 & 2.0 & 1 & N/A & [20] \\
\hline
\end{tabular}

Table 6. Protection methods for underground pipes, and their advantages.

\begin{tabular}{ccc}
\hline Protection Method & Advantages & Ref. \\
\hline Roof Box Jacking & $\begin{array}{c}\text { Reduces soil settlement and the soil load } \\
\text { Reduces soil surface settlement, pipe displacement, } \\
\text { and tension on the pipeline's crown }\end{array}$ & {$[21]$} \\
Geocell Reinforcement & Effectively reduces external earth pressures & {$[23]$} \\
\hline
\end{tabular}

Results of experimental work done by Mohammed Yousif Fattah et al. [24] show that soil settlement is reduced by between $29 \%$ and $43 \%$ by using geocell reinforcement above buried pipes. Similarly, the latest research carried out by Xiongyao Xie et al. [21] also shows the reduction in soil settlement and soil pressure using roof box jacking techniques. Further, the results of Shibu et al. [25] show a 34\% reduction in strain by using expanded polystyrene (EPS) geofoam over buried pipes. To conclude, pipeline safety from external surface loads is still in progress. In recent years, research related to live traffic loads, such as truck loads, has attracted more attention than the dead loads of superstructures or heavy machinery. Available methods are used to decrease the surface loads that are transferred to the soil. There is still a gap in inspection techniques that needs to be developed to measure the intensity of dead or live load arriving on the surface of BCPs. In the future, there could be comprehensive research carried out to define the limit for critical surface loads based on pipeline parameters, soil conditions, and soil-pipe interaction.

\subsection{Floods}

Heavy water pressure due to flooding can cause failure of BCPs. There are different types of flooding factors such as river scouring (RS), vortex induced vibration (VIV), and heavy object transportation, that can impact the stability of buried pipes. Table 7 summarizes the two types of flooding, their causes, damages, and mitigation techniques. 
Table 7. Flooding categories, causes, damages, and mitigations.

\begin{tabular}{ccccc}
\hline Type & Causes & Damage & Mitigations & Ref. \\
\hline river scouring (RS) & $\begin{array}{c}\text { Erosion of a riverbed } \\
\text { (vertical scour) or } \\
\text { riverbanks (lateral scour) }\end{array}$ & $\begin{array}{c}\text { Failure due to } \\
\text { hydrodynamic forces of } \\
\text { the flowing water }\end{array}$ & $\begin{array}{c}\text { Design of erosion } \\
\text { countermeasures }\end{array}$ & [26] \\
\hline $\begin{array}{c}\text { vortex induced } \\
\text { vibration (VIV) }\end{array}$ & $\begin{array}{c}\text { Flow perpendicular to the } \\
\text { axis of the pipeline }\end{array}$ & Fatigue failure due to VIV & $\begin{array}{c}\text { Acceptable flow } \\
\text { return frequencies }\end{array}$ & [27] \\
\hline
\end{tabular}

The sustainability of BCPs requires proper and regular inspection for safe operation. From the literature studies, various inspection techniques used for flooding control are summarized in Table 8 . The advantages and limitations of these techniques have been explained. Both classical and modern instruments are used for flood monitoring.

Table 8. Inspection Techniques for flood monitoring with advantages and limitation.

\begin{tabular}{|c|c|c|c|}
\hline Inspection Technique & Advantages & Limitations & Ref. \\
\hline $\begin{array}{l}\text { Ground Penetrating } \\
\text { Radar (GPR) }\end{array}$ & $\begin{array}{l}\text { Quick process for detection of potential } \\
\text { weak zones }\end{array}$ & $\begin{array}{l}\text { Commonly used for detection of failure in } \\
\text { flood banks }\end{array}$ & [28] \\
\hline $\begin{array}{l}\text { Japanese pipe } \\
\text { geophone system }\end{array}$ & $\begin{array}{l}\text { Useful for measurement of large stones at } \\
\text { bed level }\end{array}$ & High installation cost & [29] \\
\hline Magnetic flux leakage & $\begin{array}{c}\text { Possible to detect both external and } \\
\text { internal defects }\end{array}$ & $\begin{array}{l}\text { Not suitable for axially oriented } \\
\text { defect detection }\end{array}$ & [30] \\
\hline Electrical field signature & Simple installation procedure & Continuous contact with $\mathrm{BCPs}$ are required & [31] \\
\hline Radiography & Easily distinguishes deep layers of BCPs & $\begin{array}{l}\text { Can be the cause of damage for humans } \\
\text { and sea animals }\end{array}$ & [33] \\
\hline Fiber optics & Precise results with less loss of data & $\begin{array}{l}\text { Installation is tedious, and permanent } \\
\text { installation is required for it }\end{array}$ & [34] \\
\hline
\end{tabular}

From Table 8, it is observed that the output readings from classical instruments like acoustic emissions can be interrupted on irregular surface applications. Ground penetrating radar (GPR) and electrical field signature can provide moderate results with their continuous attachment to the observation units. Magnetic flux leakage is widely used for metal loss due to corrosion detection. The radiography method requires high care due to radio wave emission that can be harmful to human and sea animals. Nowadays, the Japanese geophone and fiber optics provide solutions for precise measurements, but their installation costs are too high.

It is noted that the failure of BCPs due to VIV loading has been comprehensively discussed in the literature. Few damage incidents due to flooding have been reported during past events. Various inspection techniques have been developed that manage the flooding action that triggers damage to BCPs.

\subsection{Blasting}

Blasting is also considered as one of the peril factors for BCPs. In the past, various experimental and numerical workings have been performed related to blasting effects on structural components such as beams and plates. However, little attention has been given to the blasting effects on BCPs. Blasting near the passage of lifelines can cause deformation in buried pipelines. Dowding's formula is commonly used to evaluate the impact of blast waves on BCPs [35]. This formula is derived for the plane wave with constant amplitude and is given in Equation (1) as;

$$
J=\frac{\frac{E}{(1+v)}}{\left[\frac{6 E I}{\left(1-v^{2}\right)}\right] \cdot \frac{1}{r^{3}}}
$$

$J$ values of more than 10 mean that BCPs are flexible in nature and bend with the ground. Similarly, for smaller $J$ values, the strain accumulated in the BCPs will be less than the adjoining soil. For a 
specific charge exploded in soil at the vicinity of an underground pipe, Esparza et al. [36] established Equation (2) to assess the stresses generated on a pipe;

$$
\frac{\delta}{E}=4.44\left[\frac{n W}{\sqrt{E h} R^{2.5}}\right]^{0.77}
$$

Moreover, it is difficult to monitor the blasting effects on BCPs in the field. However, specific criteria have been developed by various researchers for safe design and regular monitoring of BCPs. Dongwang Zhong et al. [37] presented a flow chart for safe design and regular health monitoring. They suggested that the ground peak particle velocity parameter should be considered for on-site health monitoring of BCPs due to easy procedure and consistent examination. Further, they intend to use piezoceramic patch transducers (PPTs) for health monitoring of BCPs in their future research. The concept behind the application of PPTs is due to their benefits of maximum bandwidth, twin sensing and actuation capability, and comfort of attachment to the face of BCPs.

If blasting consequences are not counted for important structural components, a preliminary blasting disaster can simply trigger further growth of damage. There is space available for health and monitoring methods to be developed for this domain. For future work, parametric studies with supplementary drag pressure effects and blast intervals could be considered. Blast proof materials for BCPs could also be introduced.

\subsection{Earthquake}

In recent years, BCPs have been severely damaged due to earthquakes. After reviewing different reports, research publications, technical notes, and design standards, it has been observed that damages to BCPs due to earthquakes have been classified into six categories, shown in Figure 6.

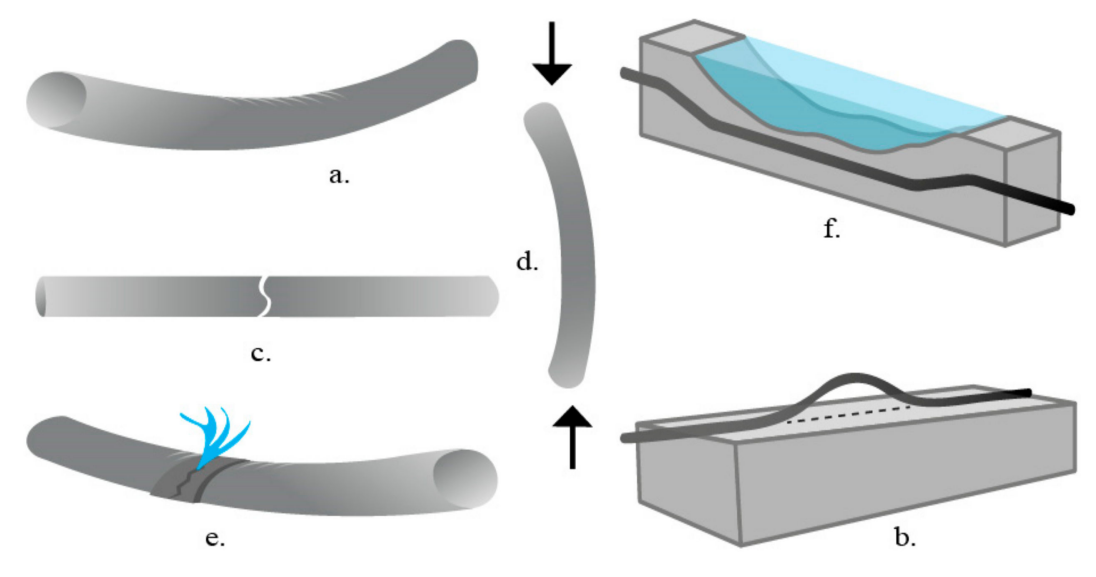

Figure 6. Common failure modes of BCPs: (a) Local buckling due to stability loss, (b) Beam buckling, (c) Tensile facture, (d) Flexural failure, (e) Welding failure, and (f) Fatigue failure.

The failure modes observed in previous major earthquakes by various researchers have been summarized in Table 9.

From Table 9, it can be observed that the most common failure mode observed in previous major earthquakes is local buckling failure followed by tensile fracture and beam buckling. Therefore, a proper design methodology should be employed to protect BCPs from these failure modes. Seismic health monitoring is considered as the essential procedure for regular inspection of existing pipelines. In the literature, several solutions are provided for health monitoring of BCPs, and the mostly used techniques include periodic sensing for short duration, real-time based sensing, and modern innovative solutions and are given in Table 10. 
Table 9. Failure modes of buried pipelines in previous major earthquakes.

\begin{tabular}{|c|c|c|c|c|c|c|c|c|}
\hline \multirow{2}{*}{ Location } & \multicolumn{2}{|l|}{ Earthquake } & \multicolumn{5}{|c|}{ Failure Modes in BCPs } & \multirow{2}{*}{ Ref. } \\
\hline & (Year-Mw) & ${ }^{\wedge} \mathrm{TF}$ & ${ }^{+} \mathrm{LBF}$ & ${ }^{\star} \mathrm{BBF}$ & ${ }^{*} \mathrm{FF}_{1}$ & "WF & 畨FF & \\
\hline San Francisco & $1906-7.8$ & $\bullet$ & $\bullet$ & $\bullet$ & & & & [38] \\
\hline Kern County & $1952-7.3$ & & $\bullet$ & & & & & [39] \\
\hline Alaska & $1964-9.2$ & & - & & & & & {$[1,39]$} \\
\hline San Fernando & $1971-6.7$ & & $\bullet$ & $\bullet$ & $\bullet$ & $\bullet$ & & [39] \\
\hline Imperial Valley & $1979-6.4$ & & & $\bullet$ & & & & [1] \\
\hline Nihonkai-Chubu & $1983-7.8$ & & • & & & & $\bullet$ & [40] \\
\hline Costa Rica & $1991-7.7$ & & $\bullet$ & & & & & {$[1]$} \\
\hline Northridge & $1994-6.7$ & $\bullet$ & $\bullet$ & & & $\bullet$ & & [41] \\
\hline Chi-Chi & 1999-7.6 & & $\bullet$ & & & & & [42] \\
\hline Central Italy & $2006-6.2$ & - & & & & & & [43] \\
\hline Peru & 2019-8.0 & & $\bullet$ & & & & & [44] \\
\hline
\end{tabular}

Table 10. Seismic inspection methods for BCPs, their advantages, and limitations.

\begin{tabular}{|c|c|c|c|}
\hline Inspection Method & Advantages & Limitations & Ref \\
\hline $\begin{array}{c}\text { Periodic } \\
\text { inspection method }\end{array}$ & $\begin{array}{l}\text { Use PIGs technology to evaluate various parameters like } \\
\text { strain measurement and crack pattern observations }\end{array}$ & $\begin{array}{l}\text { Limited to periodic } \\
\text { recordings only. PIGs } \\
\text { can be damaged. }\end{array}$ & [45] \\
\hline $\begin{array}{c}\text { Real time } \\
\text { sensing methods }\end{array}$ & $\begin{array}{c}\text { Use wireless technology, fiber optic sensing, and large area } \\
\text { networks and provide a permanent solution to pipelines } \\
\text { leakage detections }\end{array}$ & $\begin{array}{l}\text { Less costly than period } \\
\text { inspection. Applicable } \\
\text { for sensitive pipes. }\end{array}$ & [46] \\
\hline $\begin{array}{l}\text { Modern } \\
\text { innovative solutions }\end{array}$ & $\begin{array}{l}\text { Use two-dimensional (2D) strain monitoring techniques, } \\
\text { innovative materials, and modern robotic systems to } \\
\text { precisely monitor and measure cracks in BCPs. }\end{array}$ & $\begin{array}{l}\text { Not accessible to } \\
\text { everyone. Still in } \\
\text { developing stages. }\end{array}$ & [47] \\
\hline
\end{tabular}

From literature surveys, it is observed that the dominant failure mode in BCPs is the beam buckling failure. Investigations have been performed using numerical simulations rather than experimental work. Attempts should be focused on dynamic soil-pipe interaction experiments to build more consistent limit states, considering all essential factors in managing the main damage modes. There are three principal pipeline inspection techniques used in practice today: Periodic inspection, real time sensing, and modern innovative solutions. All of these methods demonstrate advantages and drawbacks from various perspectives; however, modern innovative solutions seem to be an additional smart choice in the long term. The current challenge is to effectively employ them in post-earthquake rehabilitation assessments.

\section{Results and Discussion}

Several factors have been discussed independently by many researchers in the past that can influence the sustainability of BCPs. Further, their aspects, impacts, mitigation, and inspection techniques have also been debated separately. Therefore, a review-based study was required to discuss all factors on one platform and to classify them based on their potential for damage.

This article is based on research contributions concerning screening, identification, environmental analysis, and technical based analysis, and is aimed at the evaluation of this research regarding the factors influencing the sustainability of BCPs.

Figure 7 shows the progress in mitigation and inspection tools regarding six primary factors. In the past, both modern and classical inspection techniques have been developed to preserve BCPs from corrosion and earthquake factors. Modern innovative solutions for earthquake and PIGs technology development for corrosion has placed them in the advanced stage. On the other hand, flood inspection techniques have been developed for the monitoring of flood level rather than for their application on BCPs. Inspection techniques for external surface loads were developed to reduce the external pressure on soil. Therefore, flood and external surface loads are considered as being in the developing stages. 
However, there is still space in the research for the monitoring of BCPs from the perspective of blasting and temperature variations.

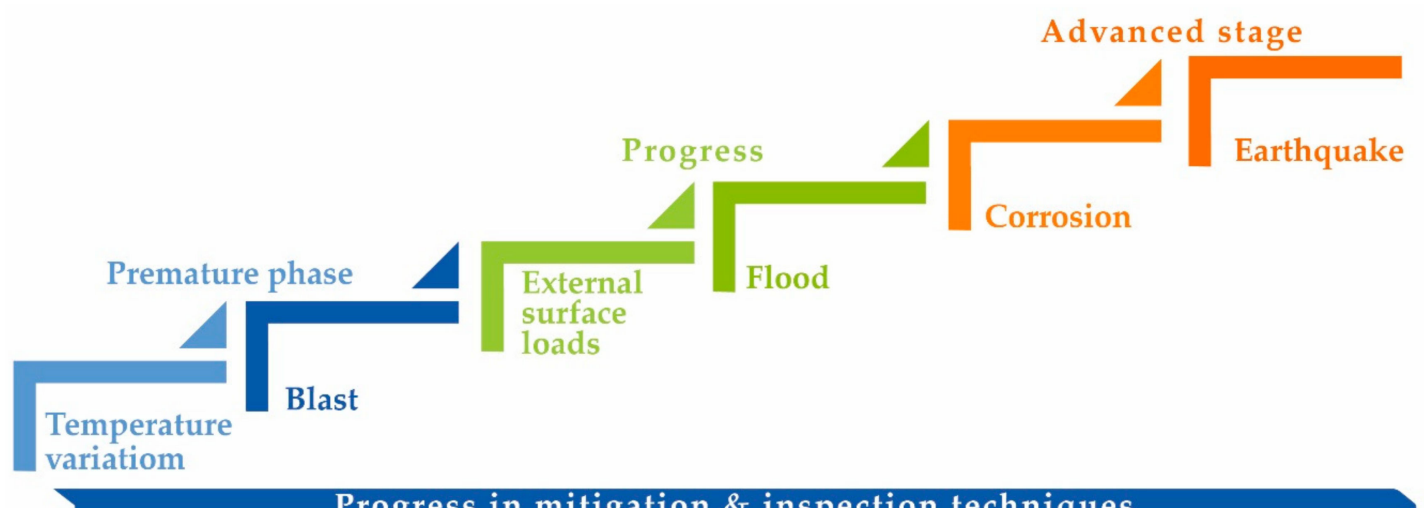

Figure 7. Progress in mitigation and inspection techniques.

The literature review performed in this research discovered that the majority of investigators are concerned with handling the problems of BCPs due to corrosion and earthquake factors. Studies regarding external surface load and flood are still in the progress stage. However, temperature variations and blast factors are in the premature phase and need broad inspection and research support.

\section{Conclusions}

In this review article, a five step methodology (problem statement, screening, environmental analysis, technical perspectives, and evaluation) has been adopted. Six primary factors have been identified based on the screening process. Further, an environmental analysis has been performed to analyze their impact on the sustainability of BCPs. Based on the analysis performed in the current review; (1) causes and damages of BCPs due to corrosion has been carefully handled and more effective approaches in the form of inspection techniques have been introduced; (2) temperature variation effect is rarely observed and only happens in regions with extreme weather changes. There is still space for contribution of research in this domain; (3) live loads (e.g., traffic load) have received more attention than dead loads (e.g., heavy buildings or machinery weight), therefore, attention is required for their safety from dead loads; (4) flooding effect is hardly discussed in the literature due to few cases being reported in this domain. Inspection techniques are developed only for flood control rather than for pipeline safety; (5) research on blast load is based on empirical equations and there is still space for advances in their health monitoring techniques; (6) the furthermost researched topic related to sustainability of BCPs is its safety from earthquakes. Advances in both seismic rehabilitation and inspection techniques have been observed in this sphere. This review article provides a platform to pipeline agencies, investigators, and standard organizations to carefully analyze the operational advances in the primary factors influencing the sustainability of BCPs.

Regarding factors influencing the sustainability of $\mathrm{BCPs}$, most studies did not contemplate various consequences. Review studies could be carried out on segmented, polyethylene, and aluminum made buried pipes to compare their sustainability and durability with BCPs. Current research could also be extended by involving the effects of secondary and tertiary factors. There could be a comparison of discussed factors based on patent and web of science analysis to check the year wise quantity and quality of publications. There could be a hybrid inspection technique to measure and monitor all the factors at one time. Collaborative exercises among research societies and BCPs manufacturers should be adopted to accomplish significant progress. 
Author Contributions: Conceptualization, M.R.A.; Formal Analysis, A.C.Z; Investigation, M.R.A.; Writing-Review \& Editing, M.R.A.; Supervision, A.C.Z. All authors have read and agreed to the published version of the manuscript and have contributed substantially to the work reported.

Funding: The authors would like to acknowledge the financial support from the Disaster and Emergency Management Presidency (AFAD), Turkey under Bilimsel Araştırma Projeleri ( BAP) project grant.

Conflicts of Interest: The author declares that there is no conflict of interest.

\section{References}

1. O'Rourke, M.J.; Liu, X. Response of Buried Pipelines Subject to Earthquake Effects; Multidisciplinary Center for Earthquake Engineering Research, State Univ. of New York at Buffalo: Buffalo, NY, USA, 1999.

2. PHMSA. Significant pipeline incidents. Available online: http://primis.phmsa.dot.gov (accessed on 20 December 2019).

3. Schweitzer, P. Corrosion and Corrosion Protection Handbook; Marcel Dekker: New York, NY, USA, 1983 ; p. 483.

4. ASTM G48 Standard test methods for pitting and crevice corrosion resistance of stainless steels and related alloys by the use of ferric chloride solution; G2MT Laboratories, LLC: Houston, TX, USA, 2015.

5. Holt, J.; Wood, G. Cavitation research facilities and techniques. In International Symposium on Cavitation Research Facilities and Techniques; American Society of Mechanical Engineers: New York, NY, USA; p. 233.

6. Kerr, S.L.; Rosenberg, K. An index of cavitation erosion by means of radioistopes. Trans. Am. Soc. Mech. Engrs. 1958, 80, 1308-1314.

7. NACE. Control of External Corrosion on Underground or Submerged Metallic Piping Systems; National Association of Corrosion Engineers (NACE): Houston, TX, USA, 2013.

8. Xu, D.; Huang, W.; Ruschau, G.; Hornemann, J.; Wen, J.; Gu, T. Laboratory investigation of MIC threat due to hydrotest using untreated seawater and subsequent exposure to pipeline fluids with and without SRB spiking. Eng. Failure Anal. 2013, 28, 149-159. [CrossRef]

9. Ebadzadsahraei, S.; Vakili, M.H. Comparison of corrosion resistance of fiberglass/epoxy and fiberglass/polyester composite pipes for application in natural gas transportation. J. Pipeline Sys. Eng. and Prac. 2019, 3. [CrossRef]

10. Walker, J. In-line Inspection of Pipelines-Advanced Technologies for Economic and Safe Operation of Oil and Gas Pipelines; Verlag Moderne Industrie: Verlag, Germany, 2010; p. 327.

11. Kishawya, H.A.; Gabbar, H.A. Review of pipeline integrity management practices. Int. J. Pressure Vessels and Piping 2010, 87, 373-380. [CrossRef]

12. Habibian, A. Effect of temperature changes on water-main breaks. Am. Soc. Civil Eng. 1994, 120. [CrossRef]

13. Muñoz, M.V. Raw water storage. case study: Göteborg's water supply. Master Thesis, Chalmers University of Technology, Göteborg, Sweden, July 2005.

14. Wu, G.Z.; Li, D.; Wei, H.C. The Feasibility discussion of application infrared imaging technology to oil and gas pipeline. Oil Gas Sto. Trans. 2005, 24, 49-50.

15. Adebayo, A.; Al-Yousef, H.; Mahmoud, M. An experimental investigation of the use of combined resistivity and temperature logs for scale monitoring in carbonate formations during CO2 sequestration. J. Energy Resour. Technol. 2015, 137, 032202. [CrossRef]

16. Arockiasamy, M.; Chaallal, O.; Limpeteeprakarn, T. Full-scale field tests on flexible pipes under live load application. J. Perf. Constructed Fac. 2006, 20, 21-27. [CrossRef]

17. Kang, J.; Stuart, S.; Davidson, J. Analytical study of minimum cover required for thermoplastic pipes used in highway construction. Struc. Infras. Eng. 2014, 10, 316-327. [CrossRef]

18. Sheldon, T.; Sezen, H.; Moore, I. Joint response of existing pipe culverts under surface live loads. J. Perf. Constructed Faci. 2015, 29. [CrossRef]

19. Brückner, J.; Marewski, U.; Steiner, M. Numerical simulation of external loads on buried pipelines. In Proceedings of the Pipeline Technology Conference, Berlin, Germany, 12-14 March 2018.

20. Fang, H.; Li, B.; Wang, F.; Wang, Y.; Cui, C. The mechanical behaviour of drainage pipeline under traffic load before and after polymer grouting trenchless repairing. Tunnelling Underground Space Tech. 2018, 74, 185-194. [CrossRef]

21. Xie, X.; Zhao, M.; Shahrour, I. Experimental Study of the Behavior of Rectangular Excavations Supported by a Pipe Roof. Appl. Sci. 2019, 9, 2082. [CrossRef] 
22. Khalaj, O.; darabi, N.j.; Tafreshi, S.N.M.; Mašek, B. Protection of buried pipe under repeated loading by geocell reinforcement. IOP Conf. Ser. Earth Environ. Sci. 2017, 95, 022030. [CrossRef]

23. Beju, Y.Z.; Mandal, J.N. Combined use of jute geotextile-EPS geofoam to protect flexible buried pipes: Experimental and numerical studies. Int. J. Geosynthetics Ground Eng. 2017, 3, 32. [CrossRef]

24. Fattah, M.Y.; Hassan, W.H.; Rasheed, S.E. Effect of Geocell Reinforcement above Buried Pipes on Surface Settlement. Int. rev. of civil eng. 2018, 9. [CrossRef]

25. Shibu, S.S.; Thomas, S. Experimental investigation on the efficiency of expanded polystyrene (EPS) geofoam and geogrid in protection of buried pipes under static loading. Mater. Sci. 2019, 6, 429-433.

26. Dooley, C.; Prestie, Z.; Ferris, G.; Fitch, M.; Zhang, H. Approaches for evaluating the vulnerability of pipelines at water crossings. In Proceedings of the 2014 International Pipeline Conference, Calgary, Alberta, Canada, 29 September-3 October 2014.

27. Heggen, H.O.; Fletcher, R.; Fyrileiv, O.; Ferris, G.; Ho, M. Fatigue of pipelines subjected to vortex-induced vibrations at river crossings. In Proceedings of the Rio Oil \& Gas Expo and Conference 2014, Brazil, Rio de Janeiro, 15-18 September 2014.

28. Sylwia Tomecka, S. Ground penetrating radar use in food prevention. Acta Geophys. 2019, 67, $1955-1965$. [CrossRef]

29. Goto, K.; Itoh, T.; Nagayama, T.; Kasai, M.; Marutani, T. Experimental and theoretical tools for estimating bedload transport using a Japanese pipe hydrophone. Int. J. Erosion Con. Eng. 2014, 7, 101-110. [CrossRef]

30. Yan, S.; Chao, Z.; Rui, L.; Maolin, C.; Guanwei, J. Theory and application of magnetic flux leakage pipeline detection. Sensors 2015, 15, 31036-31055. [CrossRef]

31. Wan, Z.; Liao, J.; Tian, G.Y.; Cheng, L. Investigation of drag effect using the field signature method. Meas. Sci. and Tech. 2011, 22. [CrossRef]

32. Liu, Y.; D' Angelo, R.M.; Choi, G.; Zhu, L.; Bose, S.; Zeroug, S. Understanding acoustic physics in oil and gas wellbores with the presence of ubiquitous geometric eccentricity. In Proceedings of the 44th Annual Review of Progress in Quantitative Nondestructive Evaluation, Provo, UT, USA, 15-16 July 2017; 16.

33. Haith, M.I.; Huthwaite, P.J.; Lowe, S.M. Defect characterisation from limited view pipeline radiography. NDT E Int. 2017, 86, 186-198. [CrossRef]

34. Seaman, C.H.; Brower, D.V.; Le, S.Q.; Tang, H.H. Development and testing of a post-installable deepwater monitoring system using fiber-optic sensors. In Proceedings of the ASME 34th International Conference on Ocean, Offshore and Arctic Engineering, St. John's, NL, Canada, 31 May 2015.

35. Dowding, C.H. Blast Vibration Monitoring and Control. In Proceedings of the 37th U.S. Symposium on Rock Mechanics (USRMS), Vail, CO, USA, 7-9 June 1999.

36. Esparza, E.D.; Westine, P.S.; Wenzel, A.B. Pipeline response to buried explosive detonations. Am. Gas Assoc. 1981, 2, 146-152.

37. Zhong, D.; Gong, X.; Han, F.; Li, L. Monitoring the Dynamic Response of a Buried Polyethylene Pipe to a Blast Wave: An Experimental Study. Appl. Sci. 2019, 9. [CrossRef]

38. O'Rourke Meyersohn, W.D.; Grigoriu, M.D.; Khater, M.M. Ground failure effects on pipeline system performance. In Proceedings of the 9th World Conference on Earthquake Engineering, Kyoto, Japan, 2-9 August 1988.

39. O'Rourke McCaffrey, M.A. Buried pipeline response to permanent earthquake ground movements. In Proceedings of the 8th World Conference on Earthquake Engineering, San Francisco, LA, USA, 21-28 July 1984.

40. Kitaura, M.; Miyajima, M. Quantitative evaluation of damage to buried pipelines induced by soil liquefaction. In Proceedings of the the 9th World Conference on Earthquake Engineering, Kyoto Japan, 2-9 August 1988.

41. Hall, J.F. Northridge earthquake of January 17, Earthquake Engineering Research Institute, reconnaissance report: volume 1. 1994. Available online: https://caltech.tind.io/record/609218?ln=en (accessed on 28 January 2020).

42. Shih, B.J.; Chang, C.H. Damage survey of water supply systems and fragility curve of PVC water pipelines in the Chi-Chi Taiwan earthquake. Natural Hazards 2006, 37, 71-85. [CrossRef]

43. GEER. Engineering Reconnaissance of the 24 August 2016 Central Italy Earthquake; GEER, NSF: Alexandria, VA, USA, 2016.

44. Strong quake in Peru kills one person, disrupts some oil operations. Reuters, 26 May 2019. Available online: https://www.reuters.com/article/us-peru-quake/strong-quake-in-peru-kills-one-persondisrupts-some-oiloperations-idUSKCN1SW06U (accessed on 18 December 2019). 
45. Glisic, B. Sensing solutions for assessing and monitoring pipeline systems. Sensor Tech. Civil Infrastructures 2014, 2, 422-460.

46. Nwalozie, G.C.; Azubogu, A.C.O. Design and implementation of pipeline monitoring system using acceleration-based wireless sensor network. Int. J. Eng.Sci. 2014, 9, 49-58.

47. Loh, K.J.; Hou, T.C.; Lynch, J.P.; Kotov, N.A. Carbon nanotube sensing skins for spatial strain and impact damage identification. J. Nondestructive Evaluation 2009, 28, 9-25. [CrossRef]

(c) (1)

(C) 2020 by the authors. Licensee MDPI, Basel, Switzerland. This article is an open access article distributed under the terms and conditions of the Creative Commons Attribution (CC BY) license (http://creativecommons.org/licenses/by/4.0/). 